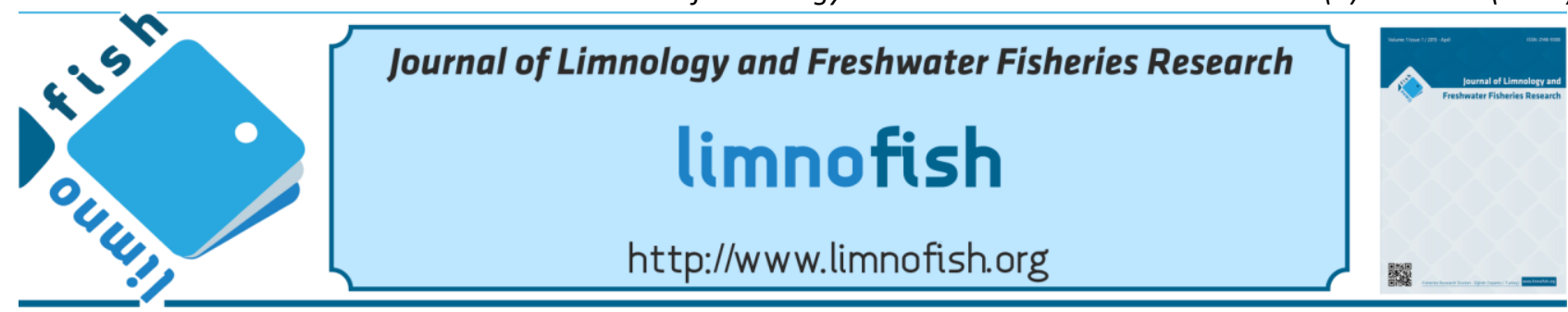

\title{
The Biodiverse Rotifers (Rotifera: Eurotatoria) of Small Wetlands of the Brahmaputra River Floodplains of Lower and Upper Assam, Northeast India
}

\author{
Bhushan Kumar SHARMA* iD, Sumita SHARMA \\ Department of Zoology, North-Eastern Hill University, Shillong - 793 022, Meghalaya, India
}

\section{A B STR ACT}

Rotifera assemblages of small floodplain wetlands (dobas or dubies) of lower and upper regions of the Brahmaputra river basin of Assam state of northeast India (NEI) reveal 157 species, belonging to 34 genera and 18 families, and highlight notable speciose constellation of up to 50 species/sample. One species, each is new to the Oriental region and Assam, and species of global and regional biogeographic interest form notable fractions. The biodiverse rotifer fauna and various interesting species are hypothesized to habitat diversity of the sampled dobas or dubies, impact of 'the Assam-gateway'- an important biogeographic corridor of India, and location of the study area in the Indo-Burmese biodiversity hot-spot. Lecanidae and Lepadellidae are species-rich families, both of lower and upper Assam wetlands; upper Assam wetlands, in particular, are characterized by a distinct paucity of the Brachionidae and Brachionus spp., the relative paucity of Trichocerca, Keratella and Mytilina species, rare occurrence of Asplanchna and Filinia species, and lack of species of Conochilidae and Hexarthridae. Our results indicate the littoral-periphytic nature and tropical character of the rotifers. Overall, this study is an important contribution to Rotifera biodiversity of small lentic habitats of India, Asia and that of the tropics and subtropics.

Keywords: Biodiversity, dobas, dubies, interesting species, 'Rotifera paradox'

\section{ARTICLE INFO}

RESEARCH ARTICLE

$\begin{array}{lll}\text { Received } & : 22.01 .2019 \\ \text { Revised } & : 16.05 .2019 \\ \text { Accepted } & : 28.05 .2019 \\ \text { Published } & : 25.12 .2019\end{array}$

DOI:10.17216/LimnoFish.515981

* CORRESPONDING AUTHOR

profbksharma@gmail.com

Phone : +91943611 0599

How to Cite

Sharma BK, Sharma S. 2019. The Biodiverse Rotifers (Rotifera: Eurotatoria) of Small Wetlands of the Brahmaputra River Floodplains of Lower and Upper Assam, Northeast India. LimnoFish. 5(3): 187-196. doi: 10.17216/LimnoFish.515981

\section{Introduction}

Small lentic ecosystems form over $90 \%$ of the standing water resources of our biosphere and $\sim 30 \%$ of the global lentic biotopes by surface area and are thus suggested to be more explicitly considered in analyses of biodiversity, limnology and global processes (Céréghino et al. 2014). They are recognized as hotspots both in terms of species composition and biological traits (EPCN 2008) and are often considered as keystone systems for the conservation of biodiversity (Oertli et al. 2010; Céréghino et al. 2014; Vad et al. 2017; Oertli 2018). The management of these biotopes and that of their metazoan diversity is usually neglected (Céréghino et al. 2008; Oertli 2018) despite more vulnerability to severe threats of extinction and habitat degradation (Moss et al. 2011). The small lentic biotopes have attracted relatively more attention in hydro-biological works from India, but the relevant literature largely depicts paucity of studies on zooplankton diversity. A critical analysis attributes this lacuna to the limited sampling, ad-hoc reports by amateurs loaded with incomplete species lists, and lack of taxonomic expertise. Nevertheless, our studies from NEI (Sharma and Sharma 2015a; Sharma and Kensibo 2017; Sharma et al. 2017) hypothesized these water bodies to be one of the biodiverse habitats of the Indian sub-region vis-à-vis Rotifera - an important group of freshwater zooplankton, an integral link of aquatic food-webs, and food for larvae and adult fish (Tuna and Ustaoğlu 2016; Apaydın Yağcı et al. 2017).

The state of Assam of NEI, a part of the IndoBurmese biodiversity hotspot, is notably known for the fluvial floodplains of the Brahmaputra river with characteristic small lentic wetlands (commonly known as dobas or dubies) forming an integral part of the rural landscape of the Brahmaputra valley. Sharma and Sharma (2014) first indicated ecological diversity importance of small wetlands in context of 
Rotifera of NEI and suggested their detailed assessment. The present study is thus an endeavor to analyze and compare species composition and richness of the rotifer assemblages of small wetlands of lower and upper reaches of the Brahmaputra river floodplains of Assam state. We provide an inventory of the documented taxa, illustrate interesting species, and comment on nature and composition of the rotifer fauna with reference to species richness, new records, important taxa, extraordinary high species consortium and elements of global and regional distribution interest. This study merits biodiversity and biogeographic interest for Rotifera of the floodplains of India, Asia as well as that of the rotifer heterogeneity of the small lentic ecosystems of the Indian sub-region.

\section{Material and Methods}

The present study is based on analysis of plankton and semi-plankton samples collected, on several occasions during 2005-2015, from small floodplain wetlands (dobas or dubies) from scattered localities (Figure 1.A-C) of Dhubri, Goalpara, Kokrajhar, Bongaigaon, Barpeta, Kamrup, Nalbari and Dispur districts of lower Assam $\left(24^{\circ} 8^{\prime}-26^{\circ} 8^{\prime} \mathrm{N} ; 8^{\circ} 8^{\prime}-92^{\circ} 2^{\prime} \mathrm{E}\right)$, and from Biswanath, Golaghat, Jorhat, Majuli, Lakhimpur,
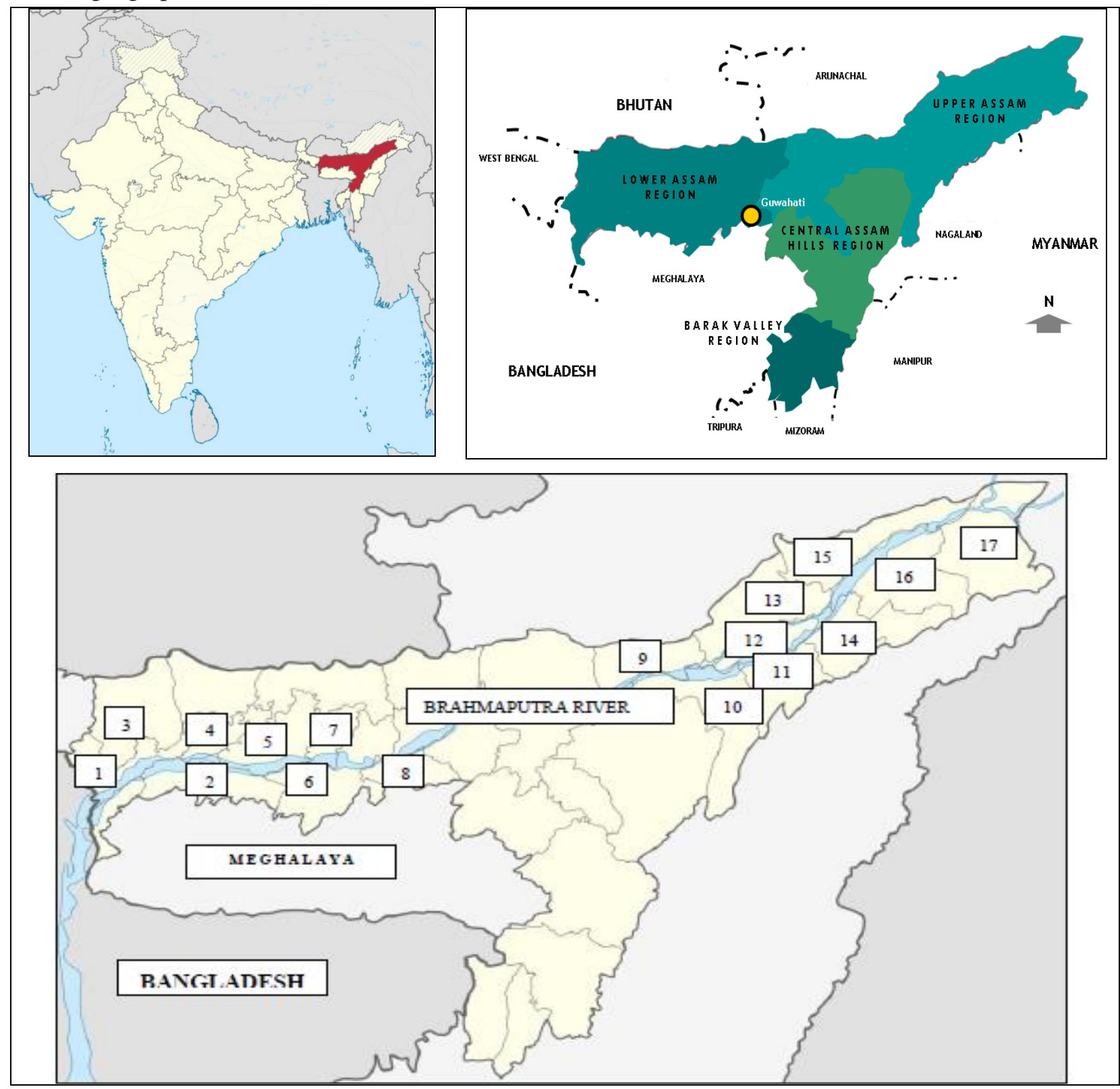

Figure 1. A-C: A, map of India indicating northeast India (NEI) and the state of Assam; B, map of Assam; C, map indicating the sampled districts of Lower Assam and Upper Assam [1-Dhubri; 2-Goalpara; 3-Kokrajhar; 4-Bongaigaon; 5-Barpeta; 6-Kamrup; 7-Nalbari; 8-Dispur; 9-Biswanath; 10-Golaghat; 11-Jorhat; 12-Majuli; 13-Lakhimpur; 14-Sibsagar;15-Dhemaji;16-Dibrugarh;17-Tinsukia] 
Sibsagar, Dhemaji, Dibrugarh and Tinsukia districts of upper Assam $\left(26^{\circ} 4^{\prime}-27^{\circ} 8^{\prime} \mathrm{N}\right.$; $93^{\circ} 8^{\prime}-95^{\circ} 6^{\prime} \mathrm{E}$ ). All the collections were made by towing nylobolt plankton net (\# size $50 \mu \mathrm{m}$ ) and were preserved in 5\% formalin. Individual samples were screened with a Wild stereoscopic binocular microscope; the rotifers were isolated and mounted in polyvinyl alcohol-lactophenol and were observed with Leica DM 1000 stereoscopic phase contrast microscope fitted with an image analyzer. Various rotifer taxa were identified following the works of Koste (1978), Segers (1995), Sharma (1998), Sharma and Sharma (1999, 2000, 2008), and Jersabek and Leitner (2013) except for two indeterminate species warranting more specimens. The biogeographic remarks were made by vide Segers (2007), Sharma and Sharma (2017) and Jersabek and Leitner (2013). The microphotographs were provided for interesting species and measurements were indicated in micrometers $(\mu \mathrm{m})$. The percentage similarity between the rotifer communities was calculated vide Sørensen's index (Sørensen 1948). The voucher collections are submitted to the holdings of Zoological Survey of India, Kolkata.

\section{Results}

The plankton and semi-plankton collections examined from small wetlands of the Brahmaputra River floodplains of lower and upper Assam reveal 157 species belonging to 34 genera and 18 families. A detailed systematic list of the observed taxa is presented below:

\begin{tabular}{|c|c|c|}
\hline \multicolumn{3}{|c|}{$\begin{array}{l}\text { Systematic list of Rotifera recorded } \\
\text { small wetlands of upper and lower Assam }\end{array}$} \\
\hline Phylum & $:$ & Rotifera \\
\hline Class & $:$ & Eurotatoria \\
\hline Subclass & $:$ & Monogononta \\
\hline Order & $:$ & Ploima \\
\hline \multirow[t]{16}{*}{ Family } & $:$ & Brachionidae \\
\hline & 1 & Anuraeopsis fissa Gosse, 1851 \\
\hline & 2 & Brachionus angularis Gosse, 1851 \\
\hline & 3 & B. bernini Leissling, 1924 \\
\hline & 4 & B. bidentatus Anderson, 1889 \\
\hline & 5 & B. budapestinensis Daday, 1885 \\
\hline & 6 & B. calyciflorus Pallas, 1766 \\
\hline & 7 & B. caudatus Barrois \& Daday, 1894 \\
\hline & 8 & $\begin{array}{l}\text { B. dichotomus reductus Koste \& Shiel, } \\
\text { 1980\#@ }\end{array}$ \\
\hline & 9 & B. diversicornis (Daday, 1883) \\
\hline & 10 & B. durgae Dhanapathi, 1974 \\
\hline & 11 & B. falcatus Zacharias, 1898 \\
\hline & 12 & B. forficula Wierzejski, 1891 \\
\hline & 13 & B. kostei Shiel, 1983 \#@ \\
\hline & 14 & B. mirabilis Daday, 1897 \\
\hline & 15 & B. nilsoni Ahlstrom,1940@ \\
\hline
\end{tabular}

16 B. quadridentatus Hermann, 1783

17 B. rubens Ehrenberg, 1838

18 Keratella cochlearis (Gosse, 1851)

19 K. edmondsoni Ahlstrom, 1943 \#

20 K. javana Hauer, 1937 \#@

21 K. lenzi Hauer, 1953

22 K. tecta (Gosse, 1851)

23 K. tropica (Apstein, 1907)

24 Plationus patulus (O.F. Muller, 1786)

25 Platyias leloupi Gillard, 1967

26 P. quadricornis (Ehrenberg, 1832)

\begin{tabular}{rrl} 
Family & $:$ & Euchlanidae \\
\hline 27 & Beauchampiella eudactylota (Gosse, \\
& $1886)$ \\
28 & Dipleuchlanis propatula (Gosse, 1886) \\
29 & Euchlanis dilatata Ehrenberg, 1832 \\
30 & E. incisa Carlin, 1939 \\
31 & E. triquetra Ehrenberg, 1838 \\
32 & Tripleuchlanis plicata (Levander, 1894)
\end{tabular}

\begin{tabular}{|c|c|c|}
\hline Family & : & Mytilinidae \\
\hline & 33 & Lophocharis salpina (Ehrenberg, 1834) \\
\hline & 34 & Mytilina acanthophora Hauer, 1938 \\
\hline & 35 & M. bisulcata (Lucks, 1912) \\
\hline & 36 & M. brevispina (Ehrenberg, 1830) \\
\hline & 37 & M. michelangellii Reid \& Turner, 1988 \\
\hline & 38 & M. ventralis (Ehrenberg, 1830) \\
\hline Family & : & Trichotriidae \\
\hline & 39 & Macrochaetus longipes Myers, 1934 \\
\hline & 40 & M. sericus (Thorpe, 1893) \\
\hline & 41 & Trichotria tetractis (Ehrenberg, 1830) \\
\hline & 42 & Wolga spinifera (Western, 1894) \\
\hline Family & : & Lepadellidae \\
\hline & 43 & Colurella adriatica Ehrenberg, 1831 \\
\hline & 44 & C. obtusa (Gosse, 1886) \\
\hline & 45 & C. uncinata (O.F. Müller, 1773) \\
\hline & 46 & $\begin{array}{l}\text { Lepadella acuminata (Ehrenberg } \\
\text { 1834) }\end{array}$ \\
\hline & 47 & L. apsicora Myers, 1934 \\
\hline & 48 & L. apsida Harring, 1916 \\
\hline & 49 & L. benjamini Harring, 1916 \\
\hline & 50 & L. biloba Hauer, 1958 \\
\hline & 51 & L. costatoides Segers, 1992 \\
\hline & 52 & L. dactyliseta (Stenroos, 1898) \\
\hline & 53 & $\begin{array}{l}\text { L.desmeti Segers and Chittapun, } \\
2001 * * \# @\end{array}$ \\
\hline & 54 & L. discoidea Segers, 1993 \# \\
\hline & 55 & L. ehrenbergi (Perty, 1850) \\
\hline & 56 & L. heterostyla (Murray, 1913) \\
\hline & 57 & L. minuta (Weber \& Montet, 1918) \\
\hline & 58 & L. ovalis (O. F. Müller, 1786) \\
\hline & 59 & L. patella (O.F. Muller, 1773) \\
\hline & 60 & L. quinquecostata (Lucks, 1912) \\
\hline & 61 & L. rhomboides (Gosse, 1886) \\
\hline & 62 & L. triptera Ehrenberg, 1830 \\
\hline & 63 & L. vandenbrandei Gillard, 1952 \#@ \\
\hline & 64 & $\begin{array}{l}\text { Squatinella lamellaris (O. F. Müller, } \\
1786 \text { ) }\end{array}$ \\
\hline
\end{tabular}




\begin{tabular}{|c|c|c|c|c|c|}
\hline Family & : & Lecanidae & Family & : & Scaridiidae \\
\hline & 65 & Lecane aculeata (Jakubski, 1912) & & 117 & $\begin{array}{l}\text { Scaridium longicaudum (O.F. Müller, } \\
1786 \text { ) }\end{array}$ \\
\hline & 66 & L. aeganea Harring, 1914 & Family & : & Trichocercidae \\
\hline & 67 & L. arcula Harring, 1914 & & 118 & Trichocerca bicristata (Gosse, 1887) \\
\hline & 68 & L. bifurca (Bryce, 1892) & & 119 & T. bidens (Lucks, 1912)@ \\
\hline & 69 & L. blachei Berzins, 1973 \# & & 120 & T. capucina (Wierzejski \& Zacharias, \\
\hline & 70 & L. bulla (Gosse, 1851) & & & 1893) \\
\hline & 71 & L. calcaria Harring \& Myers, 1926 \#@ & & 121 & T. cylindrica (Imhof, 1891) \\
\hline & 72 & L. clara $($ Bryce, 1892$) * \#$ & & 122 & T. elongata (Gosse, 1886$)$ \\
\hline & & & & 123 & T. flagellata Hauer, 1938 \\
\hline & 73 & L. closterocerca $($ Schmarda, 1898) & & 124 & T. hollaerti De Smet, 1990\#@ \\
\hline & 74 & L. crepida Harring, 1914 & & 125 & T. insignis (Herrick, 1886) @ \\
\hline & 75 & L. curvicornis (Murray, 1913) & & 126 & T. longiseta (Schrank, 1802) \\
\hline & 76 & L. decipiens (Murray, 1913) & & 127 & T. maior (Hauer, 1935) \# \\
\hline & 77 & L. dorvsimilis Trinh Dang, Segers \& & & 128 & T. pusilla (Jennings, 1903) \\
\hline & & $\begin{array}{l}\text { L. dorysimilis Trınh Dang, Segers \& } \\
\text { Sanoamuang, } 2015 \text { \#@ }\end{array}$ & & 129 & T. rattus (O.F. Müller, 1776) \\
\hline & & L. doryssa Harring, 1914 & & 130 & T. scipio (Gosse, 1886) @ \\
\hline & 78 & & & 131 & T. similis (Wierzejski, 1893) \\
\hline & 79 & L. elegans Harring, 1914 & & 132 & T. tenuior (Gosse, 1886) \\
\hline & 80 & L. flexilis (Gosse, 1886) & & 133 & T. tigris (O.F. Muller, 1786) \\
\hline & 81 & L. furcata (Murray, 1913) & & 134 & T. weberi (Jennings, 1903) \\
\hline & 81 & $\begin{array}{l}\text { L. Jurcata (Murray, } 1913 \text { ) } \\
\text { L. haliclysta Harring \& Myers, } 1926\end{array}$ & Family & : & Asplanchnidae \\
\hline & 82 & L. haliclysta Harring \& Myers, 1926 & & 135 & Asplanchna brightwelli Gosse, 1850 \\
\hline & 83 & L. hastata (Murray, 1913) & & 136 & A. priodonta Gosse, 1850 \\
\hline & 84 & L. hamata (Stokes, 1896) & Family & $:$ & Synchaetidae \\
\hline & 85 & L. hornemanni (Ehrenberg, 1834) & & 137 & Polyarthra vulgaris Carlin, 1943 \\
\hline & 86 & L. inermis (Bryce, 1892) & Family & $:$ & Dicranophoridae \\
\hline & 87 & L. inopinata Harring \& Myers, 1926 & & 138 & $\begin{array}{l}\text { Dicranophorus forcipatus (O.F. Müller, } \\
\text { 1786) }\end{array}$ \\
\hline & 88 & L. lateralis Sharma, 1978 \# & Order & : & Flosculariaceae \\
\hline & 89 & L. leontina (Turner, 1892) & Family & $:$ & Floscularidae \\
\hline & 90 & L. ludwigii (Eckstein, 1883) & & 139 & Ptygura sp. \\
\hline & 91 & L. luna (O. F. Müller, 1776) & & 140 & Sinantherina socialis (Linne, 1758) \\
\hline & 92 & L. lunaris (Ehrenberg, 1832) & & 141 & S. spinosa (Thorpe, 1893) \\
\hline & 93 & L. monostyla (Daday, 1897) & Family & $:$ & Conochilidae \\
\hline & 94 & L. nitida (Murray, 1913 & & 142 & Conochilus unicornis Rousselet, 1892 \\
\hline & & & Family & : & Hexarthridae \\
\hline & 95 & L. niwati Segers, Kotethip \& & & 143 & Hexarthra mira (Hudson, 1871) \\
\hline & & Sanoamuang, 2004 \#@ & Family & $:$ & Testudinellidae \\
\hline & 96 & L. obtusa (Murray, 1913) & & 144 & Pompholyx sulcata Hudson, 1885 \\
\hline & 97 & L. papuana (Murray, 1913) & & 145 & Testudinella amphora Hauer, 1938 \#@ \\
\hline & 98 & L. ploenensis (Voigt, 1902) & & 146 & T. brevicaudata Yamamoto, 1951\#@ \\
\hline & 99 & L. pusilla Harring, 1914 & & 147 & T. dendradena de Beauchamp, 1955 \#@ \\
\hline & 100 & L. pyriformis (Daday, 1905) & & 148 & T. emarginula (Stenroos, 1898) \\
\hline & & & & 149 & T. parva (Ternetz, 1892) \\
\hline & 101 & L. quadridentata (Ehrenberg, 1830) & & 150 & T. patina (Hermann, 1783) \\
\hline & 102 & L.rhenana Hauer, 1929@ & & 151 & T.tridentata Smirnov, 1931@ \\
\hline & 103 & L.rhytida Harring \& Myers, 1926@ & & 152 & Testudinella sp. @ \\
\hline & 104 & L. signifera (Jennings, 1896) & amily & & Trochosphaeridae \\
\hline & 105 & L. stenroosi (Meissner. 1908) & & 153 & Filinia camasecla Myers, 1938 \\
\hline & & L. stenroosl (Meissner, 1908) & & 154 & Filinia longiseta (Ehrenberg, 1834) \\
\hline & 106 & L. stichoclysta Segers, 1993 \# @ & & 155 & F. opoliensis (Zacharias, 1898) \\
\hline & 107 & L. thienemanni (Hauer, 1938) & Subclass & $:$ & Bdelloidea \\
\hline & 108 & L. undulata Hauer, 1938 & Order & $:$ & Philodinida \\
\hline & 109 & L. unguitata (Fadeev, 1925) \# & Family & $:$ & Philodinidae \\
\hline & 110 & L. ungulata (Gosse, 1887) & & 156 & Dissotrocha aculeata (Ehrenberg, 1832) \\
\hline Family & $:$ & Notommatidae & & 157 & Rotaria neptunia (Ehrenberg, 1830) \\
\hline & 111 & Cephalodella forficula Ehrenberg, 1830 & \multirow{3}{*}{\multicolumn{3}{|c|}{$\begin{array}{l}\text { * New record from the Orie } \\
\text { \# species of global biogeop } \\
\text { @ species restricted to Nor }\end{array}$}} \\
\hline & 112 & C. gibba (Ehrenberg, 1830) & & & \\
\hline & 113 & C. trigona (Rousselet, 1895) \# @ & & & \\
\hline
\end{tabular}

114 Monommata grandis Tessin,1890@

115 M, longiseta (O.F. Müller, 1786)

116 Notommata pachyura (Gosse, 1886)
Lecane clara (Bryce) is a new record (Figure 2.A) from the Oriental region (marked as $*$ ) and 
Lepadella desmeti Segers and Chittapun (Figure 2.B) is a new record from Assam state (marked as**). Brachionus dichotomus reductus (Figure 2.C), B. kostei (Figure 2.D), Cephalodella trigona, Filinia camasecla (Figure 2.E), Keratella edmondsoni, K. javana, Lecane blachei (Figure 2.F), L. calcaria (Figure 3.A), L. niwati (Figure 3.B), L. dorysimilis (Figure 3.C), L. lateralis, L. stichoclysta, L. unguitata, Lepadella desmeti, L. discoidea, $L$. vandenbrandei, Testudinella amphora, T. brevicaudata (Figure 3.D), T. dendradena, Trichocerca hollaerti (Figure 3.E) and $T$. maior are species of global bigeographic interest (marked as \#). Testudinella (Figure 3.F) sp. is yet an un-determined species awaiting description pending examination of more specimens. Our collections indicate 23 species (marked as @) with their distribution in India known to be restricted to NEI.

We report 152 and 125 rotifer species from lower and upper Assam collections, respectively (Table 1) with consistent importance of Lecanidae (45 and 42 species), Lepadellidae (21 species each) and Trichocercidae (16 and 13 species). The comparison of Rotifera species composition of the two study areas records lower richness of the Brachionidae (14 species), Brachionus (6 species) and paucity of species of Keratella and Mytilina especially in our collections from upper Assam wetlands (Table 1).

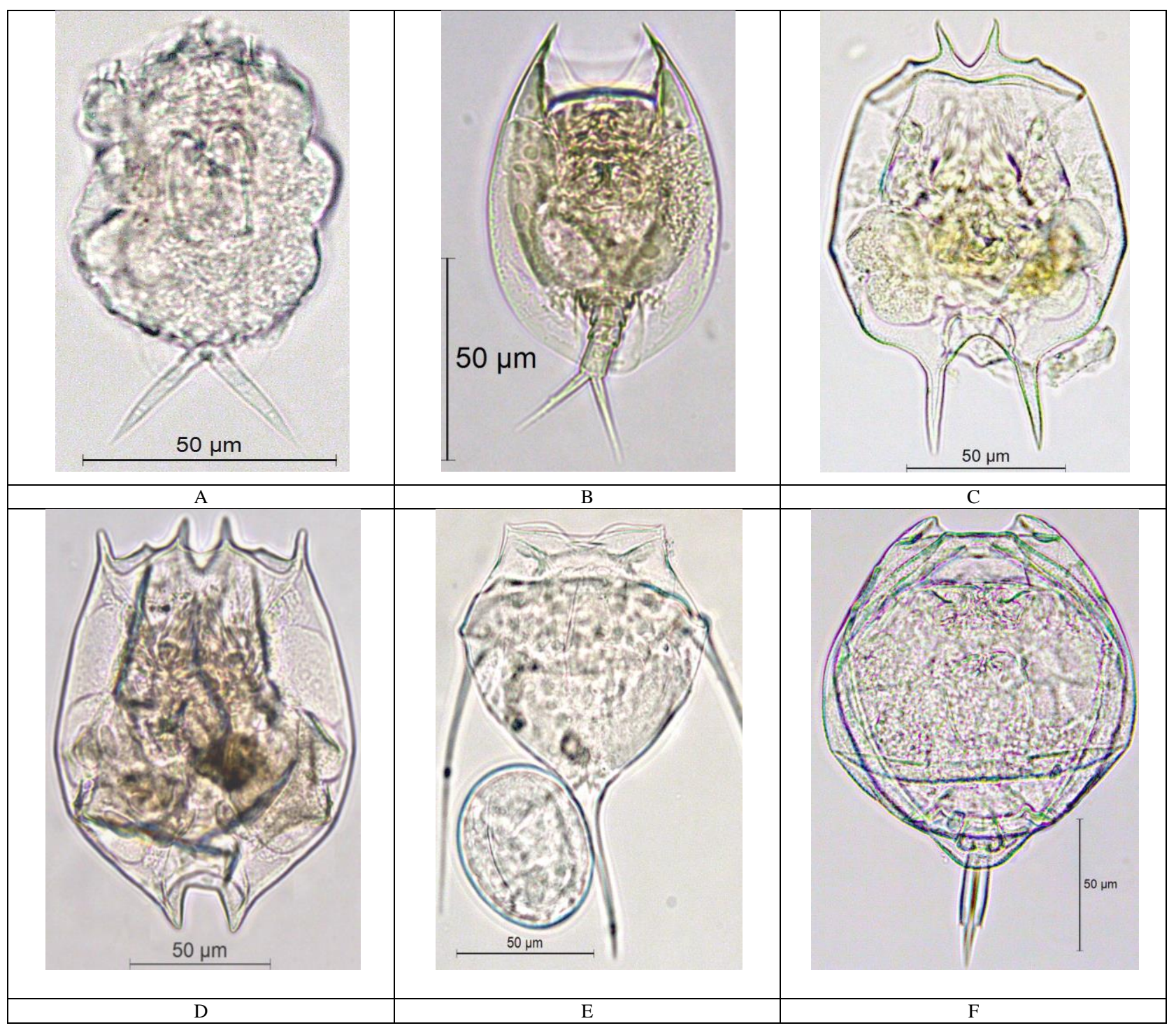

Figure 2. A-F: Rotifers of biogeographic interest (A, Lecane clara (Bryce) (dorsal view); B, Lepadella desmeti Segers and Chittapun (ventral view); C, Brachionus dichotomus reductus Koste \& Shiel (ventral view); D, Brachionus kostei Shiel (ventral view); E, Filinia camasecla Myers with parthenogenetic egg (dorsal view); F, Lecane blachei Berzins (dorsal view). 


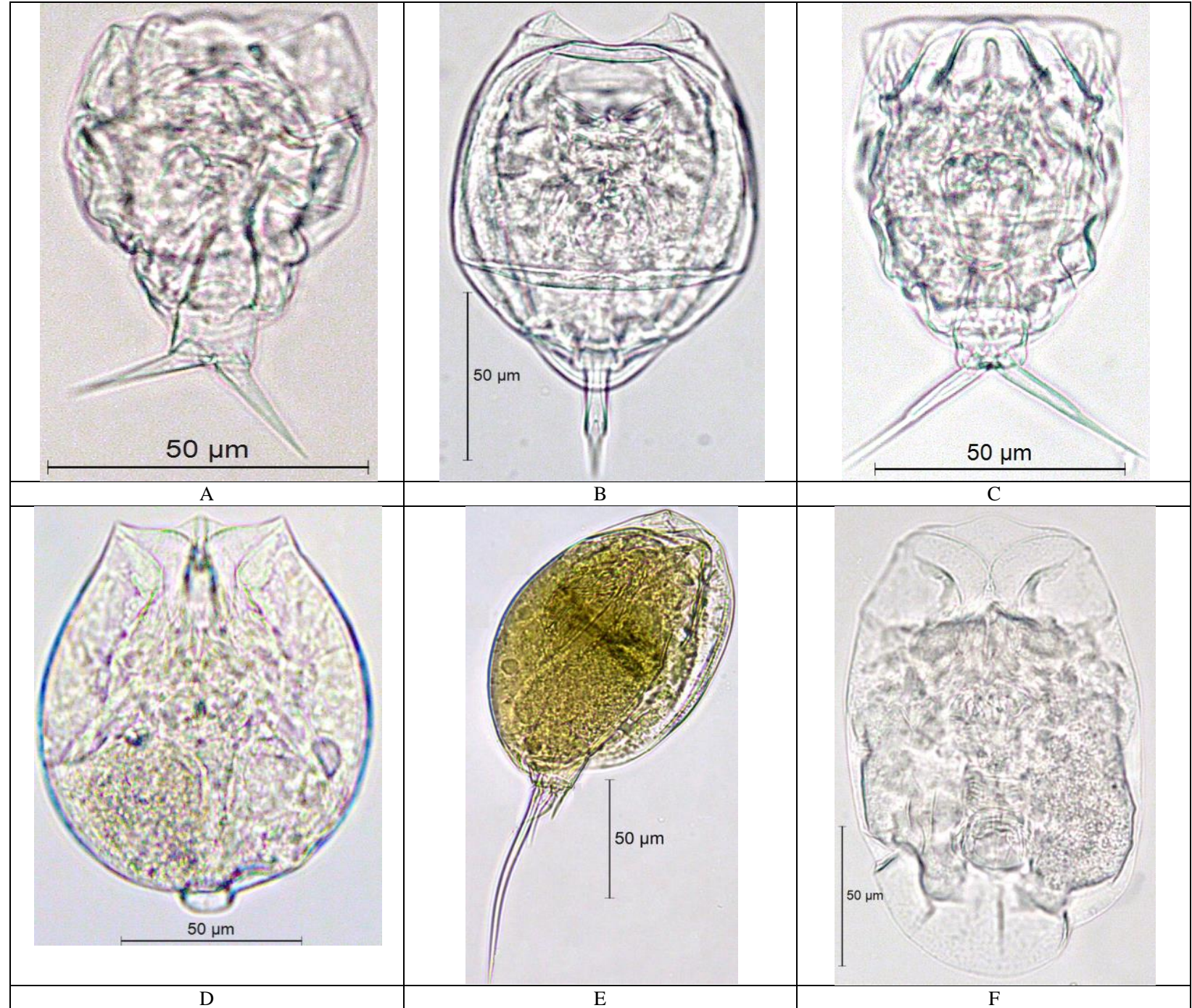

Figure 3. A-F: Rotifers of biogeographic interest (A, Lecane calcaria Harring \& Myers (ventral view); B, Lecane niwati Segers, Kotethip \& Sanoamuang (ventral view); C, Lecane dorysimilis Trinh Dang, Segers \& Sanoamuang (ventral view); D, Testudinella brevicaudata Yamamoto (ventral view); E, Trichocerca hollaerti De Smet (lateral view); F, Testudinella sp. (ventral view)

Table 1. Comparison of Rotifera composition of small wetlands of lower and upper Assam

\begin{tabular}{|c|c|c|c|}
\hline Taxa & This study & Lower Assam & Upper Assam \\
\hline Species & 157 & 152 & 125 \\
\hline Genera & 34 & 34 & 30 \\
\hline Families & 18 & 18 & 16 \\
\hline \multicolumn{4}{|c|}{ Important families: species $(\%)$} \\
\hline Lecanidae & $46(29.3 \%)$ & $45(29.6 \%)$ & $42(33.6 \%)$ \\
\hline Brachionidae & $26(16.6 \%)$ & $26(17.1 \%)$ & $14(11.2 \%)$ \\
\hline Lepadellidae & $22(14.0 \%)$ & $21(13.8 \%)$ & $21(16.8 \%)$ \\
\hline \multirow[t]{3}{*}{ Trichocercidae } & $17(10.9 \%)$ & $16(10.5 \%)$ & $13(10.4 \%)$ \\
\hline & $111(70.8 \%)$ & $108(71.0 \%)$ & $90(72.0 \%)$ \\
\hline & \multicolumn{3}{|c|}{ Other notable families: species $(\%)$} \\
\hline Testudinellidae & 8 & 8 & 7 \\
\hline Euchlanidae & 6 & 6 & 6 \\
\hline Notommatidae & 6 & 5 & 5 \\
\hline \multirow[t]{3}{*}{ Mytilinidae } & 6 & 6 & 3 \\
\hline & $26(16.6 \%)$ & $25(16.4 \%)$ & $21(16.8 \%)$ \\
\hline & \multicolumn{3}{|c|}{ Important genera: species $(\%)$} \\
\hline Lecane & $46(29.3 \%)$ & $45(29.6 \%)$ & $42(33.6 \%)$ \\
\hline Lepadella & $18(11.4 \%)$ & $16(10.5 \%)$ & $17(13.6 \%)$ \\
\hline Trichocerca & $17(10.9 \%)$ & $16(10.5 \%)$ & $13(10.4 \%)$ \\
\hline \multirow[t]{3}{*}{ Brachionus } & $16(10.2 \%)$ & $16(10.5 \%)$ & $06(4.8 \%)$ \\
\hline & $97(61.8 \%)$ & $93(61.2 \%)$ & $78(62.4 \%)$ \\
\hline & \multicolumn{3}{|c|}{ Other notable genera: species $(\%)$} \\
\hline Testudinella & 7 & 7 & 6 \\
\hline Keratella & 6 & 6 & 4 \\
\hline \multirow{2}{*}{ Mytilina } & 5 & 5 & 3 \\
\hline & $18(11.4 \%)$ & $18(11.8 \%)$ & $13(10.4 \%)$ \\
\hline
\end{tabular}




\section{Discussion}

Our collections from dobas or dubies of the Brahmaputra river basin reveal 157 species, belonging to 34 genera and 18 families; the richness comprises $\sim 65 \%, \sim 52 \%$ and $\sim 27 \%$ of species of Rotifera known from Assam state, NEI and India (Sharma and Sharma 2017), respectively and thus affirms biodiverse nature of the rotifer assemblage. Besides, 152 and 125 species observed from lower and upper Assam, respectively depict species-rich rotifers of the two study areas individually, while higher community similarity $(85.2 \%$ vide Sørensen's index) depicts overall homogeneity in species composition but with certain differences.

Lecane clara, a new record from the Oriental region, is diagnosed by its soft lorica and characteristic elongate toes. This lecanid is yet known (Segers 2007) from the African, Neotropical. Nearctic, Pacific, and Palaearctic regions, while our report extends its distribution to the Oriental region. Lepadella desmeti, described from Thailand (Segers and Chittapun 2001), is known elsewhere from Neotropical and Pacific regions (Segers 2007). The only earlier record of this species from the Indian sub-region (Sharma and Sharma 2015b) relates to Loktak Lake (a Ramsar site), Manipur state; the present study further extends its distribution within NEI to Assam state. In addition, Lecane calcaria and $L$. stichoclysta deserve mention in view of the restricted reports from south Assam (Sharma and Sharma 2019a) and the eastern Himalayas (Sharma and Sharma 2019b).

Interestingly, Rotifera of dobas or dubies invariably record species consortia of maximum 3035 species/sample while a few small wetlands from the Majuli River Island and the Dibru-Saikhowa Biosphere reserve of upper Assam indicate speciose constellations of up to 50 species/sample. We categorize these reports as 'Rotifera paradox' following analogy to the classical the paradox of the plankton` highlighted by Hutchinson (1961); the former, in turn, is hypothesized to the intriguing possibility of the co-existence of a number of species in 'a relatively isotropic or unstructured environment of small wetlands`.

This study records biodiverse rotifers than the reports from dobas or dubies of the Majuli River Island (Sharma 2014), small lentic biotopes of Mizoram (Sharma and Sharma 2015a) and Nagaland (Sharma and Kensibo 2017, Sharma et al. 2017), and the Kashmir Himalayan floodplains (Sharma and Sharma 2018). The richness is marginally lower than the reports from small lentic biotopes of the eastern Himalayas (Sharma and Sharma 2019a) and the floodplains of Barak valley of south Assam
(Sharma and Sharma 2019b). The comparisons highlight dobas or dubies of the Brahmaputra floodplains to be one of the biodiverse rotifer environs of India; this generalization is hypothesized to the function of habitat diversity of the sampled wetlands and sampling intensity vides Fontaneto et al. (2012). Interestingly, this study registers higher rotifer richness than certain global floodplain reports i.e., the Rio Pilcomayo National Park, Argentina (Jose de Paggi 2001); Oguta and Iyi-Efi lakes of the Niger delta (Segers et al. 1993) of Africa; Lake Guarana (Bonecker et al. 1994), and Lago Camaleao (Koste and Robertson 1983) of Brazil; Thale-Noi Lake, Thailand (Segers and Pholpunthin 1997); and it compares well with 151 species known from Rio Tapajos (Koste 1974) of Brazil.

Our collections reveal notable examples of global and regional biogeographic interest. The former include 21 species (13.4\%) namely (i) the Australasian Brachionus dichotomus reductus and B. kostei; (ii) the Oriental endemics Filinia camasecla, Keratella edmondsoni, L. blachei and L. niwati; (iii) the paleotropical K. javana, Lecane lateralis, L. stichoclysta, L. unguitata, Lepadella discoidea, L.vandenbrandei, Testudinella brevicaudata and Trichocerca hollaerti; (iv) the Indo-Chinese Lecane dorysimilis; (v) the Holarctic Trichocerca maior; and (vi) five other species namely Cephalodella trigona, Lecane calcaria, Lepadella desmeti, Testudinella amphora and T. dendradena. The Australian elements affirm affinity of the rotifer assemblage with Southeast Asian and Australian faunas, while other categories impart affinities with Southeast Asian Rotifera (Sharma and Sharma 2014, 2017). In addition, 23 species $(\sim 15 \%)$ are known for their Indian distribution till date restricted to NEI, while $\sim 12 \%$ species namely Brachionus durgae, Colurella adriatica, Lecane aeganea, L. doryssa, L. elegans, L. haliclysta, L. hastata, L. pusilla, L. thienemanni, Lepadella benjamini, L. dactyliseta, L. discoidea, L. quinquecostata, Macrochaetus longipes, Mytilina michelangellii, Platyias leloupi, Testudinella parva, Trichocerca flagellata and Wolga spinifera depict regional distribution interest vis-à-vis the Indian Rotifera (Sharma and Sharma 2017). We hypothesize overall biodiverse rotifer assemblage of dobas or dubies of the Brahmaputra river floodplains and occurrence of sizable fractions of specie of biogeographic interest to impact of 'the Assam-gateway' - a vital biogeographic corridor of India that facilitated extensive interchanges between the Indian and Asian biota (Mani 1974), thus changing the modern biotic composition of the 
epigean ecosystems of India into one of 'predominantly Oriental' nature (Ranga Reddy 2013).

Lecanidae > Brachionidae > Lepadellidae > Trichocercidae, collectively form large fraction $(\sim 71 \%)$ of the rotifer species known vide this study as well as from lower Assam wetlands. On the other hand, upper Assam wetlands indicate corresponding cumulative importance of these Eurotatoria families $(72 \%)$ but are characterized by a notable paucity of Brachionidae (14 species). Testudinellidae, Euchlanidae, Notommatidae, and Mytilinidae also deserve attention for collective contributions of $16.4 \%$ and $16.8 \%$ from lower and upper Assam wetlands, respectively. The 'tropic centered' Lecane is most speciose genus both of lower (45 species) and upper Assam (42 species) rotifers. Lepadella = Trichocerca $=$ Brachionus are notable in lower Assam wetlands (31.5\%), while Lepadella > Trichocerca $>$ Brachionus (29.8\%) deserve attention in upper Assam wetlands but with a distinct paucity of Brachionus spp. (6 species; 4.8\%). In general, the paucity of the brachionid Rotifera of upper Assam wetlands, concurs with the reports from the floodplains of the Majuli River Island (Sharma 2014) and our results from the states of Meghalaya (Sharma and Sharma 1999), Mizoram (Sharma and Sharma 2015a), Nagaland (Sharma et al. 2017), and Arunachal Pradesh (Sharma and Sharma 2019a) of NEI. Further, the collections from upper Assam are notable for relative paucity of Trichocerca, Keratella and Mytilina species; rare occurrence of Asplanchna and Filinia species and lack of species of Conochilidae and Hexarthridae. The richness of important Eurotatoria families and genera assigns the littoral-periphytonic nature to Rotifera of dobas or dubies of the Brahmaputra floodplains, in conformity with the reports from the floodplains of Africa (Segers et al. 1993; Green 2003), Brazil (Koste 1974; Koste and Robertson 1983), Thailand (Segers and Pholpunthin 1997), Argentina (Jose De Paggi 2001) and NEI (Sharma and Sharma 2008, 2014). The high richness of 'tropic centered' Lecane and that of Brachionus in lower Assam wetlands, large fraction of cosmopolitan species $(\sim 67 \%)$ and occurrence of several $(20 \%)$ pantropical and cosmotropical species imparts 'tropical character' to the rotifer assemblages of dobas or dubies following the reports on the tropical rotifer faunas (Fernando 1980; Segers 2008; Sharma and Sharma 2008, 2014, 2017, 2019a).

To sum up, this study is an important contribution to Rotifera biodiversity of small lentic habitats of India, Asia, and tropics and subtropics. The biodiverse rotifers affirm habitat and environmental heterogeneity of dobas or dubies of the Brahmaputra floodplains. 'Rotifera paradox' hypothesizes niche diversification enabling coexistence of several species within an unstructured environment of small wetlands. The diverse species composition is attributed to the location the sampled study areas within the key biodiversity area of the Indo-Burma Hotspot as well as the historical influence of 'the Assam-gateway' facilitating incursion of species from Asian and the Oriental faunas. Such studies need to be extended to other small lentic wetlands of NEI and elsewhere in India to explore ecosystem diversity value of small water bodies vs. biodiversity of Indian Rotifera.

\section{Acknowledgements}

The senior author (BKS) is thankful to the Ministry of Environment \& Forests (Govt. of India) for AICOPTAX research project and to a research program under "University with Potential for Excellence Program (Biosciences)" of NorthEastern Hill University, Shillong that facilitated the sampling. One of the authors (SS) thanks Drs. Ramakrishna, J.R.B. Alfred, and R.A. Khan, the former Directors, Zoological Survey of India, Kolkata for assignment of the project on "Zooplankton diversity in floodplain lakes of Assam" which also provided us partial facilities for our field work. In addition, thanks are due to Drs. L. Pachuau, M.K. Hatimuria, G. Thangjam, K.R. Sounii Pou, S.I. Khan and N. Noroh for their help in the field collections on several occasions. The authors have no conflict of interests. We thank our three anonymous reviewers for useful comments and suggestions.

\section{References}

Apaydın Yağcı M, Yeğen V, Yağcı A, Uysal R. 2017. A preliminary study on zooplankton species in different aquatic habitats of Anatolia (Turkey). Journal of Limnology and Freshwater Fisheries Research 3(1):45-50. doi:10.17216/LimnoFish.277465

Bonecker CC, Lansac-Tôha FA, Staub A. 1994. Qualitative study of Rotifers in different environments of the high Parana River floodplain (Ms), Brazil. Rev UNIMAR 16(1): 1-16.

Céréghino R, Biggs J, Oertli B, Declerck S. 2008. The ecology of European ponds: defining the characteristics of a neglected freshwater habitat. Hydrobiologia 597(1): 1-6. doi:10.1007/978-90-481-9088-1_1

Céréghino R, Boix D, Cauchie HM, Martens K, Oertli B. 2014. The ecological role of ponds in a changing world. Hydrobiologia 723(1):1-6. doi:10.1007/s10750-013-1719-y 
EPCN, 2008. The European Pond Conservation Network. The Pond Manifesto. Available from: http://campus.hesge.ch/epcn/projects.asp.

Fernando CH. 1980. The freshwater zooplankton of Sri Lanka, with a discussion of tropical freshwater zooplankton composition. Internationale Revue der gesamten Hydrobiologie und Hydrographie 65(1): 411-426. doi:10.1002/iroh.19800650310

Fontaneto D, Márcia Barbosa A, Segers H, Pautasso M. 2012. The 'rotiferologist' effect and the other global correlates of species richness in rotifers. Ecography 35(2):174-182 doi:10.1111/j.1600-0587.2011.06850.x

Green J. 2003. Associations of planktonic and periphytic rotifers in a tropical swamp, the Okavango Delta, Southern Africa. Hydrobiologia 490(1-3):197-209. doi:10.1023/A:1023475217987

Hutchinson GE. 1961. The paradox of the plankton. The American Naturalist 95(882):137-145. doi: 10.1086/282171

Jersabek CD, Leitner MF. 2013. The Rotifer World Catalog. World Wide Web electronic publication $\{17.07 .2018\}$. http://www.rotifera.hausdernatur.at/accessed

José De Paggi S. 2001. Diversity of Rotifera (Monogononta) in wetlands of Rio Pilcomayo national park, Ramsar site (Formosa, Argentina). Hydrobiologia 462(1-3):25-34. doi:10.1023/A:1013157914860

Koste W. 1974. Zur Kenntnis der Rotatorien fauna der 'schwimmenden Weise 'einer Ufer lagune in der Varzea Amazoniens, Brasilien. Amazoniana 5(1): 25-59.

Koste W. 1978. Rotatoria. Die Rädertiere Mitteleuropas, begründet von Max Voigt. Überordnung Monogononta, Gebrüder Borntaeger, Berlin, Stuttgart. I. 673 pp U. II. Tafelbd. (T. 234).

Koste W, Robertson B. 1983. Taxonomic studies of the Rotifera (Phylum Aschelminthes) from a central Amazonian varzea lake, Lago Camaleao (Ilha de Marchantaria, Rio Solimoes, Amazonas, Brazil). Amazoniana 7(2):225-254.

Mani MS. 1974. Biogeographical evolution in India. In: Mani MS, editor Ecology and Biogeography in India. The Hague: Dr. W. Junk b.v. Publishers. p. 698-724.

Moss B, Kosten S, Meerhof M, Battarbee R, Jeppesen E, Mazzeo N, Havens K., Lacerot G, Liu Z, De Meester L, Paerl H, Scheffer M. 2011. Allied attack: climate change and eutrophication. Inland Waters $1(2): 101-105$. doi:10.5268/IW-1.2.359

Oertli B. 2018. Freshwater biodiversity conservation: The role of artificial ponds in the 21st century. Aquatic Conservation: Marine and Freshwater Ecosystems 28(2):264-269. doi:10.1002/aqc.2902.

Oertli B, Biggs J, Cereghino R, Declerck S, Hull A., Miracle MR. (Eds.). 2010. Pond Conservation in Europe. Dordrecht, the Netherlands: Springer. doi:10.1007/978-90-481-9088-1
Ranga Reddy Y. 2013. Neodiaptomus prateek n. sp., a new freshwater copepod from Assam, India, with critical review of generic assignment of Neodiaptomus spp. and a note on diaptomid species richness (Calanoida: Diaptomidae). Journal of Crustacean Biology 33(6):849-865. doi:10.1163/1937240X-00002195

Segers H. 1995. Rotifera 2: Lecanidae. In: Dumont HJ, Nogrady T, editors Guides to identification of the microinvertebrates of the continental waters of the world. Amsterdam, the Netherlands: SPB Academic Publishing.6 p. 1-226.

Segers H. 2007. Annotated checklist of the rotifers (Phylum Rotifera), with notes on nomenclature, taxonomy and distribution. Zootaxa 1564(1): 1-104. doi:10.11646/zootaxa.1564.1.1

Segers H. 2008. Global diversity of rotifers (Rotifera) in freshwater. Hydrobiologia 595:49-59. doi: 10.1007/s10750-007-9003-7

Segers H, Chittapun S. 2001. The interstitial Rotifera of a tropical freshwater peat swamp on Phuket Island, Thailand. Belgian Journal of Zoology 131(2): 25-31

Segers H, Nwadiaro CS, Dumont HJ. 1993. Rotifera of some lakes in the floodplain of the river Niger (Imo State, Nigeria). II. Faunal composition and diversity. Hydrobiologia 250: 39-61. doi:10.1007/BF00007494

Segers H, Pholpunthin P. 1997. New and rare Rotifera from Rivers for Life Thale Noi Lake, Pattalang Province, Thailand, with a note on the taxonomy of Cephalodella (Notommatidae). Annales de Limnologie 33:13-21. doi:10.1051/limn/1997001

Sharma BK 1998. Freshwater Rotifers (Rotifera: Eurotatoria). Fauna of West Bengal, State Fauna Series 3(11): 341-361. Zoological Survey of India, Calcutta.

Sharma BK. 2014. Rotifers (Rotifera: Eurotatoria) from wetlands of Majuli - the largest river island, the Brahmaputra river basin of upper Assam, northeast India. Check List 10(2): 292-298. doi:10.15560/10.2.292

Sharma BK, Kensibo. 2017. Rotifer assemblages (Rotifera: Eurotatoria) of two wetlands of Nagaland, northeast India: ecosystem diversity and interesting features. International Journal of Fisheries and Aquatic Studies 5(2): 609-617.

Sharma, BK, Kensibo and Sharma S. 2017. Biodiversity of rotifers (Rotifera: Eurotatoria) of Nagaland, northeast India; richness, composition and ecosystem diversity. International Journal of Fisheries and Aquatic Studies 5(5):180-187.

Sharma BK, Sharma S. 1999. Freshwater Rotifers (Rotifera: Eurotatoria). Fauna of Meghalaya: State Fauna Series 4(9):11-161 Zoological Survey of India, Calcutta.

Sharma BK, Sharma S 2000. Freshwater Rotifers (Rotifera: Eurotatoria). Fauna of Tripura: State Fauna Series 7(4): 162-224. Zoological Survey of India, Calcutta. 
Sharma BK, Sharma S. 2014. Northeast India: An important region with a rich biodiversity of Rotifera. In: Sharma BK, Dumont HJ, Wallace RL (eds.) Rotifera XIII: Rotifer Biology - A structural and functional Approach. International Review of Hydrobiology 99(1-2): 20-37. doi:10.1002/iroh.201301701

Sharma BK, Sharma S. 2015a. Biodiversity of freshwater rotifers (Rotifera: Eurotatoria) of Mizoram, Northeast India: composition, new records and interesting features. International Journal of Aquatic Biology 3(5): 301-313.

Sharma BK, Sharma S. 2015b. The diversity and distribution of Lepadellidae (Rotifera: Eurotatoria: Monogononta) of India. International Review of Hydrobiology 100 (1): 34-42. doi: 10.1002/iroh.201401739

Sharma BK, Sharma S. 2017. Rotifera: Eurotatoria (Rotifers). In: Chandra K, Gopi KC, Rao DV, Valarmathi K, Alfred JRB, editors Current status of freshwater faunal diversity in India. p. 93-113. Zoological Survey of India, Kolkata.

Sharma BK, Sharma S. 2018. The rotifers (Rotifera: Eurotatoria) from the Kashmir Himalayan floodplains and Rotifera biodiversity of Jammu \& Kashmir, north India. International Journal of Aquatic Biology 6(4): 208-220. doi:10.22034/ijab.v6i4.507

Sharma BK, Sharma S. 2019a. The biodiverse rotifer assemblages (Rotifera: Eurotatoria) of Arunachal
Pradesh, the eastern Himalayas: alpha diversity, distribution and interesting features. Bonn zoological Bulletin 68(1):1-12. doi:10.20363/BZB-2019.68.1.001

Sharma BK, Sharma S. 2019b. The biodiverse rotifers (Rotifera: Eurotatoria) of the floodplain wetlands of Barak valley of Assam state, northeast India. Opuscula Zoologica, Budapest 50(1):3-15. doi:10.18348/opzool.2019.1.3

Sharma S, Sharma BK. 2008. Zooplankton diversity in floodplain lakes of Assam. Records of the Zoological Survey of India, Occasional Paper No: 290: 1-307.

Sørensen T. 1948. A method of establishing group of equal amplitude in plant sociology based on similarity of species content and its application to analyse the vegetation of Danish Commons. Kongelige Danske Videnskabernes Selskab, Biologiske Skrifter 5(4): 1-34.

Tuna A, Ustaoğlu MR. 2016. The Zooplankton Fauna of Kemer Dam Lake (Aydın-Turkey). Journal of Limnology and Freshwater Fisheries Research 2(2):95-106. doi: 10.17216/LimnoFish-5000183782

Vad CF, Péntek A, Cozma NJ, Földi A, Tóth A, Tóth B, Böde NA, Móra A, Ptacnik R, Ács E, Zsuga K, Horvátha Z. 2017. Wartime scars or reservoirs of biodiversity? The value of bomb crater ponds in aquatic conservation. Biological Conservation 209: 253-262.

doi:10.1016/j.biocon.2017.02.025 